\title{
Bio-guided bioactive profiling and HPLC- DAD fingerprinting of Ukrainian saffron (Crocus sativus stigmas): moving from correlation toward causation
}

Olha Mykhailenko ${ }^{1+}$ (D) Vilma Petrikaite ${ }^{2,3+}$ (D) Michal Korinek ${ }^{4,5,6,7^{*}}$ (D), Mohamed El-Shazly, ${ }^{8,9}$ (D) Bing-Hung Chen ${ }^{5,10}$ (D), Chia-Hung Yen ${ }^{4}$, Chung-Fan Hsieh ${ }^{11}$, Ivan Bezruk ${ }^{1}$ (D), Asta Dabrišiūté ${ }^{2}$, Liudas Ivanauskas ${ }^{12}$ (D),

Victoriya Georgiyants ${ }^{1}$ (D) and Tsong-Long Hwang ${ }^{6,7,13,14^{*}}$ (D)

\begin{abstract}
Background: Saffron or stigmas of Crocus sativus L. is one of the most valuable food products with interesting health-promoting properties. C. sativus has been widely used as a coloring and flavoring agent. Stigmas secondary metabolites showed potent cytotoxic effects in previous reports.

Methods: The present study investigated the chemical composition and the cytotoxic effect of Ukrainian saffron crude extracts and individual compounds against melanoma IGR39, triple-negative breast cancer MDA-MB-231, and glioblastoma U-87 cell lines in vitro using MTT assay. Several bioactivity in vitro assays were performed. The chemical profile of the water and hydroethanolic $(70 \%, v / v)$ crude extracts of saffron stigmas was elucidated by HPLC-DAD analysis.

Results: Seven compounds were identified including crocin, picrocrocin, safranal, rutin, apigenin, caffeic acid, ferulic acid. Crocin, picrocrocin, safranal, rutin, and apigenin were the major active constituents of Ukrainian C. sativus stigmas. The hydroethanolic extract significantly reduced the viability of MDA-MB-231 and IGR39 cells and the effect was more potent in comparison with the water extract. However, the water extract was almost 5.6 times more active against the $U-87$ cell line ( $E C_{50}$ of the water extract against $U-87$ was $0.15 \pm 0.02 \mathrm{mg} / \mathrm{mL}$, and $\mathrm{EC}_{50}$ of the hydroethanolic extract was $0.83 \pm 0.03 \mathrm{mg} / \mathrm{mL}$ ). The pure compounds, apigenin, and caffeic acid also showed high cytotoxic activity against breast cancer, melanoma, and glioblastoma cell lines. The screening of the biological activities of stigmas water extract (up to $100 \mathrm{\mu g} / \mathrm{mL}$ ) including anti-allergic, anti-virus, anti-neuraminidase, and antiinflammatory effects revealed its inhibitory activity against neuraminidase enzyme by $41 \%$.
\end{abstract}

\footnotetext{
*Correspondence: michalk@kmu.edu.tw; htl@mail.cgu.edu.tw

${ }^{+}$Olha Mykhailenko and Vilma Petrikaite contributed equally to this work.

${ }^{4}$ Graduate Institute of Natural Products, College of Pharmacy, Kaohsiung Medical University, Kaohsiung 80708, Taiwan

${ }^{6}$ Graduate Institute of Natural Products, College of Medicine, Chang Gung University, Taoyuan 33302, Taiwan

Full list of author information is available at the end of the article
}

(c) The Author(s). 2021 Open Access This article is licensed under a Creative Commons Attribution 4.0 International License, which permits use, sharing, adaptation, distribution and reproduction in any medium or format, as long as you give appropriate credit to the original author(s) and the source, provide a link to the Creative Commons licence, and indicate if changes were made. The images or other third party material in this article are included in the article's Creative Commons licence, unless indicated otherwise in a credit line to the material. If material is not included in the article's Creative Commons licence and your intended use is not permitted by statutory regulation or exceeds the permitted use, you will need to obtain permission directly from the copyright holder. To view a copy of this licence, visit http://creativecommons.org/licenses/by/4.0/. The Creative Commons Public Domain Dedication waiver (http://creativecommons.org/publicdomain/zero/1.0/) applies to the data made available in this article, unless otherwise stated in a credit line to the data. 
Conclusions: The presented results revealed the qualitative and quantitative chemical composition and biological activity of Crocus sativus stigmas from Ukraine as a source of natural anticancer and neuraminidase inhibitory agents. The results of the extracts' bioactivity suggested future potential applications of saffron as a natural remedy against several cancers.

Keywords: Crocus sativus, Stigmas, Crude extract, HPLC, Cytotoxic activity

\section{Background}

Saffron (C. sativus stigmas) is one of the most expensive spices that is cultivated in a few countries around the world [1]. The peculiarity of this spice along with its unique color and taste attracted the attention of scientists to investigate its nutritional and therapeutic properties [1, 2]. Saffron was used as a medicinal plant long before its use as a spice [3]. The healing properties of saffron against many human diseases were documented by ancient Mediterranean, Persian, and Arabian civilizations. Since the beginning of the twentieth century, a plethora of studies investigated the chemical and therapeutic properties of saffron using modern analytical, pharmacological, and clinical techniques to confirm its traditional use $[2,3]$.

The main producing countries of C. sativus are Iran, Morocco, and Spain. Italy, India, and France produce fewer quantities $[2,3]$. The cultivation area of saffron is limited by environmental factors that affect its ontogenesis. Since 2015, Ukrainian farmers started the widespread cultivation of saffron for food-grade purposes [4]. Climatic conditions including temperature, humidity, light radiation, altitude, and soil conditions are different across Ukraine. These differences may affect the chemical composition and consequently the pharmacological properties of C. sativus harvested from different areas in Ukraine. Saffron is gaining popularity in Ukraine not only as a spice but as a medicinal raw material in folk medicine for eye diseases, diabetes, acute respiratory viral diseases, and cancers $[5,6]$. According to the international standards (ISO/Technical Specification 3632), saffron stigmas from Ukraine are considered of high quality [4]. However, a complete chemical analysis of saffron cultivated in Ukraine has not yet been performed.

Cancer is one of the most devastating diseases that usually requires treatment with surgery and chemotherapy. These chemotherapeutics are known for dreadful effects on the quality of life and resistance triggering properties [7]. Therefore, there is a continuing need to search for alternative treatments from natural sources to decrease the dependence on chemical therapeutic agents and reduce chemotherapeutics' toxic side effects. Among various uses of saffron, it is also considered a potential antitumor natural remedy [3]. The literature contains encouraging data on the antitumor activity of various saffron extracts and their components $[8,9]$, thus our attention was drawn to investigate the effects against some of the less-studied cancer cell lines.

The objective of this study was to compare the phytochemical content of the water and hydroethanolic $(70 \%$, v/v) crude extracts of $C$. sativus stigmas. The cytotoxic activity of the extracts and several individual compounds of saffron stigmas was evaluated against human melanoma IGR39, triple-negative breast cancer MDA-MB-231, and glioblastoma U-87 cell lines. Additionally, various bioactivities including antiallergic, anti-inflammatory, anti-viral, or anti-neuraminidase bioactivities of the water extract were assessed.

\section{Methods}

\section{Reagents and chemicals}

Acetonitrile and methanol were of HPLC grade and purchased from Roth GmbH (Karlsruhe, Germany). Reference compounds (crocin, safranal, apigenin, rutin, caffeic acid, ferulic acid, chlorogenic acid, gallic acid) were purchased from ChromaDex (Santa Ana, CA), SigmaAldrich (Saint Louis, MO), HWI Analytik GmbH, and Roth GmbH (Karlsruhe, Germany).

\section{Plant material}

Crocus sativus L. (Iridaceae family) flowers were collected from the plantation in the village Lyubimivka (Kherson region, Ukraine) in November 2019 in accordance with the WHO Guidelines on Good Agricultural and Collection Practices (GACP) [10, 11]. The permission for harvest was obtained from the farmers according to the cooperation agreement. The raw material was collected and identified by Dr. Mykhailenko and the identification was verified by Dr. Gamulya (V.M. Karazin Kharkiv National University, Kharkiv, Ukraine). A specimen was deposited at the Herbarium of V.M. Karazin Kharkiv National University, Ukraine $(\mathrm{CWN}$, voucher specimen No. CWN0056541). The flowers were collected manually, then the stigmas (saffron) were separated and dried for $2-3 \mathrm{~h}$ at $50^{\circ} \mathrm{C}$ under forced air. Dried stigmas were stored in dark glass jars at $4{ }^{\circ} \mathrm{C}$.

\section{Preparation of $C$. sativus stigmas extracts}

Water extract of $C$. sativus stigmas. Saffron was ground in a mortar using a pestle. $5 \mathrm{~g}$ of stigmas powder was macerated with hot distilled water $\left(500 \mathrm{ml}, 80^{\circ} \mathrm{C}\right)[12$, 
13], kept in a dark place for $24 \mathrm{~h}$, then the extract was filtered. Maceration was repeated 2 more times with the residue under the same conditions. The resulting mixtures were combined, filtered, dried on a rotary evaporator at $80^{\circ} \mathrm{C}$.

C. sativus stigmas hydroethanolic $(70 \%, \mathrm{v} / \mathrm{v})$ extract was obtained with the same above method using ethanol/water $70 / 30(\mathrm{v} / \mathrm{v})(5 \mathrm{~g}, 500 \mathrm{~mL})$ instead of water as the extracting solvent.

\section{Sample preparation for analysis}

The dried extract (water and hydroethanolic, the weight of each sample was $0.01 \mathrm{~g}$ ) was extracted with $10 \mathrm{~mL}$ of methanol using an ultrasonic bath at room temperature $\left(20 \pm 2{ }^{\circ} \mathrm{C}\right)$ for $30 \mathrm{~min}$. The solution was filtered using a membrane filter $(0.45 \mu \mathrm{m})$ before use. An aliquot of $10 \mu \mathrm{L}$ was injected into the HPLC system for analysis. A standard solution was prepared by dissolving reference compounds including crocin, safranal, rutin, caffeic acid, chlorogenic acid, gallic acid, ferulic acid, and apigenin in methanol $(1.0 \mathrm{mg} / \mathrm{mL})$. These solutions were used for calibration. All samples were kept at $4{ }^{\circ} \mathrm{C}$ before use.

\section{HPLC conditions}

Chromatographic separation of compounds was carried out using an ACE $\mathrm{C}_{18}$ column $(250 \mathrm{~mm} \times 4.6 \mathrm{~mm}$, $5.0 \mu \mathrm{m}$; Pennsylvania, USA). Elution was performed at a flow rate of $1 \mathrm{~mL} / \mathrm{min}$. The binary solvent system of the mobile phase consists of solvent A $(0.1 \%$ acetic acid in water) and solvent B (acetonitrile). All solvents were filtered through a $0.23 \mu \mathrm{m}$ membrane filter after ultrasonic degassing. A gradient elution was applied: $0 \mathrm{~min}-95 \%$ $\mathrm{A}$ and $5 \% \mathrm{~B}, 7 \mathrm{~min}-95 \% \mathrm{~A}$ and 5\% B, $67 \mathrm{~min}-0 \% \mathrm{~A}$ and $100 \% \mathrm{~B}, 69 \mathrm{~min}-95 \% \mathrm{~A}$ and $5 \% \mathrm{~B}, 75 \mathrm{~min}-95 \% \mathrm{~A}$ and $5 \% \mathrm{~B}$. The column temperature was constant at $25{ }^{\circ} \mathrm{C}$. The injection volume of the sample solution was $10 \mu \mathrm{L}$. The standard solutions including crocin, safranal, rutin, apigenin, caffeic acid, chlorogenic acid, gallic acid, and ferulic acid were used for the calibration of a standard curve using an external standard method. The picrocorcin content in the extracts was recalculated as safranal equivalent. Analysis was performed in duplicate. Validation of the HPLC method was performed according to certain parameters [14] including specificity, linearity, precision, the limit of detection (LOD), and limit of quantitation (LOQ) (Tables 1 and 2).

\section{Apparatus}

Liquid chromatography separation was performed using the Shimadzu Nexera X2 LC-30 AD HPLC system (Shimadzu, Japan) formed of a quaternary pump, an on-line degasser, a column temperature controller, the SIL-30 AC autosampler (Shimadzu, Japan); the CTO-20 AC thermostat (Shimadzu, Japan), SPD-M20A diode array detector (DAD). Ultrasonic Cleaner Set as used for ultra-sonication (Wise Clean WUC-A06H, Witeg Labortechnik GmbH, Germany), pH-meter - Knick Electronic Battery-operated pH Meter 911 PH (Portamess, Germany), rotary evaporator (Heidolph 2 WB eco, Laborata400 efficient, Germany).

\section{Data analysis}

All data processing was carried out using LabSolutions Analysis Data System (Shimadzu Corporation). Statistical analysis was performed by one-way analysis of variance (ANOVA) followed by Tukey's multiple comparison test with the software package Prism v.5.04 (GraphPad Software Inc., La Jolla, CA, USA). A $p$-value $<0.05$ was considered significant.

\section{Cell culture}

Human melanoma cancer cell line IGR39, human triplenegative breast cancer cell line MDA-MB-231, and human glioblastoma U-87 cell lines were obtained from the American Type Culture Collection (ATCC, Manassas, VA, USA). Cells were grown in DMEM Glutamax medium (Gibco, Carlsbad, CA, USA) containing 10\% fetal bovine serum and $1 \%$ antibiotic mixture $(10,000 \mathrm{U} /$ $\mathrm{mL}$ penicillin and $10 \mathrm{mg} / \mathrm{mL}$ streptomycin; Gibco). All cells were incubated at $37^{\circ} \mathrm{C}$ in a humidified atmosphere containing $5 \% \mathrm{CO}_{2}$.

Table 1 Calibration curves of the quantified reference standard compounds

\begin{tabular}{|c|c|c|c|c|c|c|}
\hline Compound & Calibration curve $^{a}$ & Correlation coefficient $r^{2}(n=6)$ & Linear range $(\mu \mathrm{g} / \mathrm{mL})$ & RSD, \% & $\operatorname{LOD}^{\mathbf{b}}(\mathrm{ng} / \mathrm{mL})$ & $\mathrm{LOQ}^{\mathrm{c}}(\mathrm{ng} / \mathrm{mL})$ \\
\hline 1 Caffeic acid & $y=57,646.8 x-3853.48$ & 0.9999218 & $0.72-91.92$ & 1.56 & 20 & 60 \\
\hline 2 Ferulic acid & $y=54,955.4 x-638.345$ & 0.9999592 & $0.44-56.5$ & 1.60 & 30 & 80 \\
\hline 3 Rutin & $y=16,072.5 x+1499.73$ & 0.9998787 & $0.16-20.24$ & 1.07 & 96 & 290 \\
\hline 4 Crocin & $y=3789.03 x+220.836$ & 0.999588 & $1.15-147.2$ & 1.28 & 100 & 300 \\
\hline 5 Apigenin & $y=50,138.3 x+5722.97$ & 0.9998899 & $0.2-25.76$ & 0.53 & 25 & 80 \\
\hline 6 Safranal & $y=39,230.1 x-11,887.2$ & 0.999529 & $1.33-42.56$ & 1.35 & 120 & 360 \\
\hline 7 Gallic acid & $y=32,880.6 x-612.983$ & 0.9999718 & $0.48-61.08$ & 1.31 & 30 & 100 \\
\hline 8 Chlorogenic acid & $y=29,930.2 x-538.361$ & 0.9999502 & $0.36-46$ & 1.29 & 20 & 70 \\
\hline
\end{tabular}

Note: ${ }^{a}$ concentration of compound $(\mathrm{mg} / \mathrm{mL}) ; \mathrm{y}$, peak area; ${ }^{b} \mathrm{LOD}$, limit of detection $(\mathrm{S} / \mathrm{N}=3) ;{ }^{\mathrm{c}} \mathrm{LOQ}$, limit of quantification $(\mathrm{S} / \mathrm{N}=10)$ 
Table 2 Precision and repeatability of the quantified compounds

\begin{tabular}{|c|c|c|c|c|c|c|c|c|}
\hline \multirow{2}{*}{\multicolumn{2}{|c|}{ Compound }} & \multirow{3}{*}{$\begin{array}{l}\text { Concentrate } \\
(\mu \mathrm{g} / \mathrm{mL})\end{array}$} & \multicolumn{4}{|l|}{ Precision } & \multicolumn{2}{|c|}{ Repeatability } \\
\hline & & & \multicolumn{2}{|c|}{ Intra-Day $(n=3)$} & \multicolumn{2}{|c|}{ Inter-Day $(n=3)$} & \multirow{2}{*}{$\begin{array}{l}\text { Recovery } \\
\text { (\%) }\end{array}$} & \multirow{2}{*}{$\begin{array}{l}\text { RSD } \\
\text { (\%) }\end{array}$} \\
\hline & & & RSD (\%) & Accuracy (\%) & $\begin{array}{l}\text { RSD } \\
(\%)\end{array}$ & Accuracy (\%) & & \\
\hline \multirow[t]{3}{*}{1} & Caffeic acid & 11.49 & 1.05 & 102.02 & 0.52 & 98.49 & 100.01 & 0.46 \\
\hline & & 45.96 & 1.08 & 98.78 & 0.67 & 99.73 & 99.39 & 0.99 \\
\hline & & 91.92 & 0.64 & 100.35 & 0.95 & 98.17 & 100.17 & 0.37 \\
\hline \multirow[t]{3}{*}{2} & Ferulic acid & 7.06 & 0.68 & 100.22 & 0.90 & 98.29 & 99.11 & 0.69 \\
\hline & & 28.25 & 0.93 & 98.20 & 0.29 & 99.31 & 99.60 & 0.57 \\
\hline & & 56.5 & 1.22 & 100.24 & 0.46 & 98.28 & 100.12 & 0.49 \\
\hline \multirow[t]{3}{*}{3} & Rutin & 2.53 & 1.26 & 100.35 & 0.62 & 100.15 & 100.18 & 0.55 \\
\hline & & 10.12 & 1.29 & 101.12 & 0.80 & 99.21 & 100.65 & 0.92 \\
\hline & & 20.24 & 0.76 & 99.56 & 1.14 & 100.94 & 99.78 & 0.31 \\
\hline \multirow[t]{3}{*}{4} & Crocin & 1.23 & 0.87 & 102.5 & 0.80 & 101.36 & 101.07 & 0.85 \\
\hline & & 18.4 & 1.25 & 99.19 & 0.91 & 100.37 & 98.99 & 1.06 \\
\hline & & 73.6 & 1.22 & 98.97 & 0.81 & 100.27 & 100.29 & 0.98 \\
\hline \multirow[t]{3}{*}{5} & Apigenin & 4 & 0.74 & 100.75 & 0.57 & 98.76 & 100.56 & 0.79 \\
\hline & & 16 & 0.89 & 100.89 & 0.29 & 98.62 & 98.96 & 0.71 \\
\hline & & 32 & 0.88 & 100.70 & 0.70 & 98.03 & 99.80 & 1.02 \\
\hline \multirow[t]{3}{*}{6} & Safranal & 1.33 & 0.57 & 101.53 & 0.67 & 101.07 & 100.27 & 0.65 \\
\hline & & 10.64 & 0.78 & 98.68 & 0.53 & 99.14 & 99.58 & 0.77 \\
\hline & & 42.56 & 1.02 & 100.47 & 0.86 & 100.12 & 99.14 & 1.04 \\
\hline \multirow[t]{3}{*}{7} & Gallic acid & 7.65 & 0.57 & 99.81 & 0.75 & 101.37 & 101.07 & 0.65 \\
\hline & & 30.35 & 0.78 & 99.56 & 0.24 & 102.14 & 99.69 & 0.56 \\
\hline & & 61.20 & 1.02 & 101.53 & 0.38 & 101.32 & 100.09 & 0.94 \\
\hline \multirow[t]{3}{*}{8} & Chlorogenic acid & 5.75 & 1.31 & 101.12 & 0.38 & 98.40 & 100.69 & 0.86 \\
\hline & & 23 & 0.42 & 99.08 & 0.73 & 99.43 & 99.58 & 1.05 \\
\hline & & 46 & 0.96 & 100.27 & 0.48 & 98.24 & 101.91 & 0.97 \\
\hline
\end{tabular}

\section{Cell viability assay}

The cells were treated with saffron extracts and their viability was determined by the MTT assay (Sigma-Aldrich Co.) as described elsewhere [15]. The cells were exposed to various concentrations of the tested extracts (from $1 \mathrm{mg} / \mathrm{mL}$ to $31.25 \mu \mathrm{g} / \mathrm{mL}$ ), and after measurement of formazan solution absorbance, $\mathrm{EC}_{50}$ (half-maximal effective concentration of a drug/extract at which $50 \%$ of its maximum response is observed) values were calculated.

\section{Antiallergic activity in RBL-2H3 cells}

A methylthiazole tetrazolium (MTT) assay was used to measure the possible toxic effects of the samples on RBL-2H3 cells as previously described [16]. The maximally tolerated dose of DMSO was $0.5 \%$, not affecting RBL-2H3 cell growth. Triton X- 100 (0.5\% solution) was used as the positive control causing the death of all cells in a well. The water stigmas extract was then subjected to an anti-allergic degranulation assay based on $\beta$ - hexosaminidase release in RBL-2H3 mast cells induced by calcium ionophore (A23187) or antigen (IgE plus DNP-BSA) according to the previous methodology [17, 18]. Briefly, RBL-2H3 cells seeded in the 96-wells plate $\left(2 \times 10^{4}\right.$ cells/well, A23187-induced assay) or 48 -wells plate $\left(3 \times 10^{4}\right.$ cells/well, antigen-induced assay) at $37^{\circ} \mathrm{C}$ in $5 \% \mathrm{CO}_{2}$ atmosphere for at least $5 \mathrm{~h}$. then they were treated with samples or medium (untreated control) for $20 \mathrm{~h}$. Cells were stimulated by the addition of calcium ionophore A23187 $(1 \mu \mathrm{M})$ or cross-linking antigen DNPBSA $(100 \mathrm{ng} / \mathrm{mL})$ to previously sensitized cells with antiDNP IgE $(0.1 \mu \mathrm{g} / \mathrm{mL})$. After $1 \mathrm{~h}$ of incubation, the unstimulated cells were either lysed with $0.5 \%$ Triton X100 solution for the total amount of $\beta$-hexosaminidase release or left untreated for the spontaneous release of $\beta$-hexosaminidase. Then aliquots of the wells' supernatants $(50 \mu \mathrm{L})$ were incubated with an equal volume $(50 \mu \mathrm{L})$ of $1 \mu \mathrm{M}$ of $\mathrm{p}$-NAG ( $p$-nitrophenyl- $N$-acetyl- $\beta$-Dglucosaminide, in $0.1 \mathrm{M}$ citrate buffer, $\mathrm{pH} 4.5$ ) serving as the substrate for the released $\beta$-hexosaminidase. After 1 
h of incubation at $37^{\circ} \mathrm{C}$, the reaction was quenched by the addition of $100 \mu \mathrm{L}$ of stop buffer $\left(0.1 \mathrm{M} \mathrm{Na} \mathrm{Na}_{2} /\right.$ $\mathrm{NaHCO}_{3}, \mathrm{pH}$ 10.0). Absorbance was measured at 405 $\mathrm{nm}$ on a microplate reader and the percentage inhibition of $\beta$-hexosaminidase release was calculated.

\section{Anti-inflammatory activity in human neutrophils}

Blood was taken from healthy human donors using a protocol approved by the Chang Gung Memorial Hospital review board. Neutrophils were isolated following the standard procedure [19]. The inhibition of superoxide anion generation (respiratory burst) was measured based on ferricytochrome $c$ reduction as previously described [20]. Briefly, preheated neutrophils $\left(6 \times 10^{5}\right.$ cells $\cdot \mathrm{mL}^{-1}$ ) and $0.5 \mathrm{mg} / \mathrm{mL}$ ferricytochrome $c$ solution were treated with the tested compounds or DMSO (control) for $5 \mathrm{~min}$, and activated with formyl-methionylleucyl-phenylalanine (fMLF, $100 \mathrm{nM}$ )/cytochalasin B $(\mathrm{CB}, 1 \mu \mathrm{g} / \mathrm{mL})$ for $10 \mathrm{~min}$. The absorbance was continuously monitored at $550 \mathrm{~nm}$ using Hitachi U-3010 spectrophotometer with constant stirring (Hitachi Inc., Tokyo, Japan). Calculations were based on the differences in absorbance with and without superoxide dismutase (SOD, $100 \mathrm{U} / \mathrm{mL}$ ) divided by the extinction coefficient for the reduction of ferricytochrome $c(\varepsilon=$ $21.1 / \mathrm{mM} / 10 \mathrm{~mm}$ ). Elastase release (i.e., degranulation from azurophilic granules) was evaluated as described before [21]. Briefly, neutrophils were equilibrated with elastase substrate, $\mathrm{MeO}$-Suc-Ala-Ala-Pro-Val-p-nitroanilide $(100 \mu \mathrm{M})$, at $37^{\circ} \mathrm{C}$ for $2 \mathrm{~min}$ and then incubated with the sample for $5 \mathrm{~min}$. Cells were activated by 100 $\mathrm{nM}$ fMLF and $0.5 \mu \mathrm{g} / \mathrm{mL} \mathrm{CB}$, and changes in the absorbance at $405 \mathrm{~nm}$ corresponding to elastase release were continuously monitored. The results were expressed as the percent of the initial rate of elastase release in the fMLF/CB-activated drug-free control system.

\section{Lipid droplet assay}

Lipid droplet assay was performed according to a previous method using a BSA-conjugated oleic acid system in Huh7 cells as described previously [22]. Briefly, cells seeded in $\mu$ Clear ${ }^{\circ}$ 96-wells plates (Greiner Bio-ONE, Frickenhausen, Germany) were treated with oleic acid and the tested sample or DMSO for $18 \mathrm{~h}$. Paraformaldehyde was used to fix the cells, which were stained with $2 \mu \mathrm{g} / \mathrm{mL}$ Hoechst 33342 and $1 \mu \mathrm{g} / \mathrm{mL}$ BODIPY $^{\odot} 493 / 503$. High Content Imaging (HCS) instrument was used to take and analyze images of the nuclei and lipid droplets (ImageXpress Micro System, Molecular Devices, Sunnyvale, CA, USA). The diameter settings were $8-25 \mu \mathrm{m}$ for the nuclei and $0.5-2 \mu \mathrm{m}$ for the lipid droplets.

\section{NRF2 activity}

Nuclear transcription factor NRF2 activity was evaluated in HacaT normal cells and Huh7 cancer cells according to a previous methodology [23]. The cell line $\mathrm{HaCaT} /$ ARE (antioxidant response element) was developed using a $\mathrm{HaCaT}$ stable cell line carrying a fragment derived from pGL4.37[luc2P/ARE/Hygro] plasmid and the luciferase reporter gene luc2P. The reporter cells were cultured in Dulbecco's Modified Eagle's Medium (DMEM) (Gibco BRL, Grand Island, NY, USA) supplemented with penicillin $(100 \mathrm{U} / \mathrm{mL})$, streptomycin $(100 \mu \mathrm{g} / \mathrm{mL}), 10 \%$ heat-inactivated fetal bovine serum (HyClone, Logan, UT, USA), and $100 \mu \mathrm{g} / \mathrm{mL}$ hygromycin at $37^{\circ} \mathrm{C}$ in $5 \% \mathrm{CO}_{2}$. The cells were seeded $\left(1 \times 10^{4}\right.$ cells/ well) in a 96-wells plate and treated with the sample for $18 \mathrm{~h}$ (single measurement). Resazurin (Cayman Chemical, Ann Arbor, MI, USA, final concentration of $0.1 \mathrm{mg} /$ $\mathrm{mL}$ ) was added and the cells were incubated for an additional $4 \mathrm{~h}$ at $37^{\circ} \mathrm{C}$. Fluorescence of the reduced resazurin in the supernatant of the cells (ex/em: $530 \mathrm{~nm} / 590$ $\mathrm{nm}$ ) was detected using a Synergy HT Multi-Mode Reader (BioTek, Winooski, VT, USA) to determine cell viability. The cells were then harvested, and luciferase activity was measured according to the manufacturer's protocol (Promega Corporation, Madison, WI, USA). The luciferase activity was normalized to cell viability.

\section{Protective against influenza and enterovirus}

The anti-viral assay was performed by cytopathic effects of the extracts on the cells infected by influenza H1N1 [24], and enterovirus D68 [25]. Briefly, the 96-well tissue culture plates were seeded with MDCK cells $\left(2 \times 10^{4}\right.$ per well) or RD cells $\left(2 \times 10^{4}\right.$ cells /well $)$ in E10 medium (DMEM containing 10\% FBS, $100 \mathrm{U} / \mathrm{mL}$ penicillin (Gibco, USA), $100 \mu \mathrm{g} / \mathrm{mL}$ streptomycin (Gibco, USA), 2 mM L-glutamine (L-glutamine) (Gibco, Brazil), $0.1 \mathrm{mM}$ nonessential amino acid mixture (NEAA, Gibco, USA) and incubated under $5 \% \mathrm{CO}_{2}$ for $16-24 \mathrm{~h}$ at $37^{\circ} \mathrm{C}$. Then, the culture medium was withdrawn and the wells were washed once with Dulbecco's phosphate-buffered saline (DPBS). The cells were infected with influenza virus (A/ WSN/33) or enteroviruses at a nine-fold median tissue culture infective dose, with or without the addition of the samples. The treated cells were further incubated for $72 \mathrm{~h}$ at $37^{\circ} \mathrm{C}$. After $72 \mathrm{~h}$, the medium was removed, and the cells were fixed with $4 \%$ paraformaldehyde for $1 \mathrm{~h}$ at room temperature. Then, $0.1 \%$ crystal violet was used to stain the cells for $20 \mathrm{~min}$ at room temperature. The cells density was measured by using a VICTOR ${ }^{\text {Tx }}$ multilabel plate reader (PerkinElmer).

\section{Neuraminidase activity assay}

A baculovirus displayed neuraminidase NA9 on the surface (NA9-Bac) as a pseudotyped influenza virus was 
used to evaluate the neuraminidase activity. An appropriate virus load of NA9-Bac was added into a 96-well plate and incubated with the extracts or compounds for $20 \mathrm{~min}$ at $37^{\circ} \mathrm{C}$. Then, each well was supplemented with $25 \mu \mathrm{L}$ of diluted fluorescent MUNANA substrate. After incubation for $30 \mathrm{~min}$ at ambient temperature, $150 \mu \mathrm{L}$ of stop solution was added. The fluorescence intensity was immediately detected using Synergy HT Multi-Mode Microplate Reader (BioTek). Zanamivir, a known neuraminidase inhibitor, was used as a positive control in this assay.

\section{Results and discussion}

According to the reported data, the cytotoxic properties against different cancer cell lines were found for both the water and hydroethanolic extracts of $C$. sativus stigmas $[1-3,7,9]$. However, the research on the cytotoxic properties of Crocus spp. extracts against melanoma IGR39, triple-negative breast cancer MDA-MB-231, and glioblastoma U-87 cell lines is still lacking. Therefore, we studied the chemical composition and cytotoxic activity of Ukrainian saffron crude extracts against these cell lines, in addition to other bioactivities screening, to understand the potential applications of this medicinal plant.

\section{HPLC method validation}

A validation study was conducted to demonstrate the applicability of the developed analytical method. The validation was done in terms of specificity, linearity, LOD, LOQ, precision, and recovery according to the International Conference on Harmonization guidelines [14]. The results are summarized in Tables 1 and 2. The regression equation for each reference standard compound, together with the LOD and LOQ values, are shown in Table 1. All the calibration curves showed acceptable linear regression $\left(r^{2} \geq 0.999\right)$. The overall intraday and interday precision RSDs were not more than $2.0 \%$. The overall stability over $24 \mathrm{~h}$ and repeatability were not more than $2.0 \%$ for both parameters. The developed analytical method showed excellent precision with overall recovery in the range from 98 to $101 \%$ (RSD $\leq 2.0 \%)$ for all compounds. Therefore, the method was precise, accurate, and sensitive enough for the simultaneous quantitative evaluation of all compounds in $C$. sativus extracts.

The specificity is the ability of a method to discriminate between the study analytes and other constituents in the sample. Specificity was demonstrated by the separation of the analytes from other interfering compounds. The determination of the main compounds in the tested solutions was done by comparing the retention times of the peaks and UV-spectrum with those of the standard solution. The results showed that the conditions for the fingerprint analysis were repeatable and precise.

\section{Qualitative and quantitative analysis of the compounds}

The extraction of the biologically active components from C. sativus stigmas was carried out under optimal conditions by maceration at room temperature in the dark to minimize the decomposition of the phenolic compounds and carotenoids [26]. To identify the composition of the active ingredients in the tested extracts, an HPLC-DAD method was used. The HPLC chromatograms of Crocus water and hydroethanolic $(70 \%, \mathrm{v} / \mathrm{v})$ crude extracts are shown in Figs. 1, 2 and 3. The determination of the compounds in the tested extracts was done by comparing the peak retention times and the UV spectra obtained from the chromatogram of the standard solution. The results of the components of the analysis of the crude extracts of Ukrainian C. sativus stigmas are presented in Table 3. Among the main and speciesspecific compounds in C. sativus stigmas extracts, the presence of crocin, safranal, and picrocrocin was analyzed. According to the published data, the quantitative content of crocin in the dried C. sativus stigmas from Italy, Greece, France, Spain varied depending on the growing conditions and processing methods. It ranged from 6 to $16 \%$ up to $30 \%$ [27].

In the current study, the content of crocin in Ukrainian saffron was $38 \mathrm{mg} / \mathrm{g}(3.8 \%)$ in the water and $163 \mathrm{mg} /$ g $(16.3 \%)$ in the hydroethanolic extract, respectively (Table 3). For comparison, the content of crocin (identified as trans-crocetin bis( $\beta$-D-gentiobiosyl) ester) in the methanol extracts of the Iranian and Azerbaijan saffron was 45.99 and $48.47 \mathrm{mg} / \mathrm{g}$, respectively, and for the alcoholic extract from the Spanish saffron, the content was $11.95 \mathrm{mg} / \mathrm{g}$ [28]. Thus, the content of crocin in Ukrainian samples was at least 2-3 times higher. The high content of secondary metabolites in the Ukrainian saffron extracts might be due to concomitant factors including the location of the cultivation site, altitude, soil type, climate, quality of planting material, irrigation periods, and harvest time. Previously, we investigated the chemical composition of $C$. sativus stigmas from different regions of Ukraine and the results showed high content of crocin, picrocrocin, and safranal in the raw materials [4].

The content of picrocrocin was recalculated as a safranal equivalent and was detected in the hydroethanolic extract reaching the maximum limit described in the literature of $197 \mathrm{mg} / \mathrm{g}$ (19.7\%). Picrocrocin was detected in a lower concentration in the water extract $(62 \mathrm{mg} / \mathrm{g})$. In previous studies, the content of picrocrocin was determined in the range of $7-16 \%$ in saffron samples [29]. The content of picrocrocin in saffron methanol extract from Azerbaijan was only $26.93 \mathrm{mg} / \mathrm{g}$. This value was obtained using Waters HPLC system, a Spherisorb 


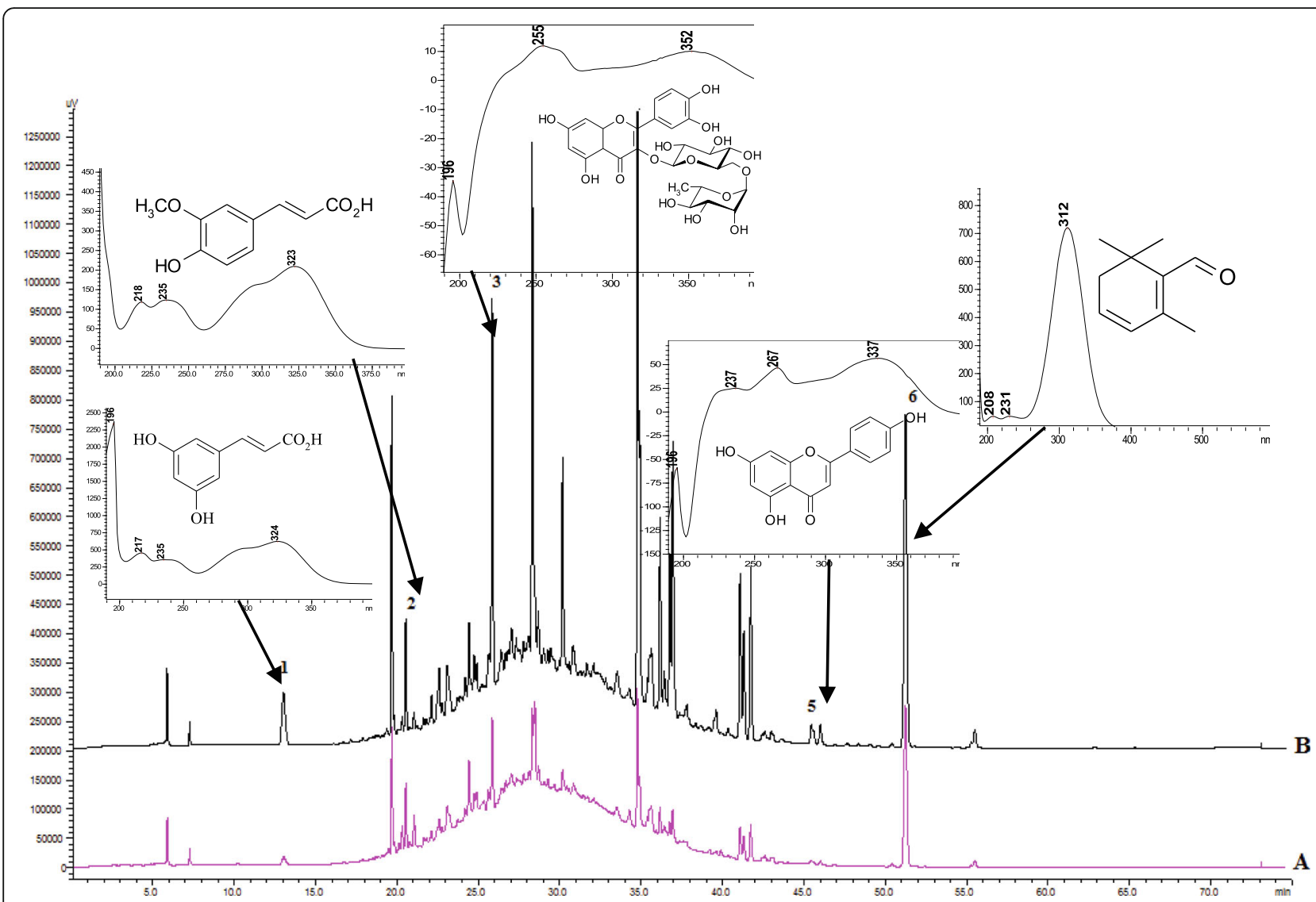

Fig. 1 HPLC-DAD chromatograms of C. sativus stigmas water (A pink line) and hydroethanolic (70\%, v/v) (B black line) crude extracts: caffeic acid (1); ferulic acid (2); rutin (3); apigenin (5); safranal (6). The detection wavelength was set at $310 \mathrm{~nm}$

ODS2 column $(250 \times 4.6 \mathrm{~mm}$ internal diameter $)$ and the used mobile phase was a linear gradient of methanol in water from 10 to $100 \%$ containing $15 \%$ acetonitrile [28]. In the current analysis, we applied the Shimadzu system and ACE $\mathrm{C}_{18}$ column $(250 \mathrm{~mm} \times 4.6 \mathrm{~mm}, 5.0 \mu \mathrm{m})$. The selected gradient system of mobile phases consisted of solvent A $(0.1 \%$ acetic acid in water) and solvent B (acetonitrile). This system provided the best peak separation. The selection of 257,330 , and $440 \mathrm{~nm}$ as the detection wavelengths resulted in an acceptable response and allowed the detection of all three major compounds (crocin, picrocrocin, and safranal), phenolic acids, and flavonoids. The column temperature was maintained at $25^{\circ} \mathrm{C}$ throughout the analysis. HPLC fingerprints for $C$. sativus stigmas extracts were developed.

In the studied crude extracts of Ukrainian saffron, the safranal content was $146.6 \mathrm{mg} / \mathrm{g}$ in the hydroethanolic and $10.81 \mathrm{mg} / \mathrm{g}$ in the stigmas water extract. In previous studies, the content of safranal in saffron raw materials from Spain was $6 \mathrm{mg} / \mathrm{g}[27,30]$, and for the Iranian saffron, the values were $0.07-0.29 \mathrm{mg} / \mathrm{g}$ [31]. The analysis of ethanol, water, and methanol-water extracts of saffron stigmas from Saudi Arabia indicated the presence of lower concentrations of crocin $(10-16 \mathrm{mg} / \mathrm{g})$ and safranal $(5 \mathrm{mg} / \mathrm{g})$ in comparison with our results [32].

In addition to the esters of crocetin, picrocrocin, and safranal, other biologically active compounds were identified in the Ukrainian saffron extracts. The current research presents the first data on the identification of flavonoid apigenin and rutin in C. sativus stigmas. It should be noted that the content of rutin and apigenin in the hydroethanolic C. sativus stigmas extract was significantly higher $(14.8 \mathrm{mg} / \mathrm{g}$ and $8.38 \mathrm{mg} / \mathrm{g}$, respectively) than in the water extract $(3.07 \mathrm{mg} / \mathrm{g}$ and $0.96 \mathrm{mg} / \mathrm{g})$.

According to the literature data, different phenolic acids such as caffeic, chlorogenic, and gallic were identified in the $C$. sativus stigmas [1]. Ferulic acid was only found in C. cancellatus subsp. damascenus stigmas [33]. However, in the crude extracts of Ukrainian saffron, chlorogenic and gallic acids were not identified. Ferulic and caffeic acids were found in the hydroethanolic extract of the Ukrainian stigmas extracts at 0.26 and $0.38 \mathrm{mg} / \mathrm{g}$, respectively. In conclusion, the content of all detected constituents in the hydroethanolic extract was much higher than in the water extract. 


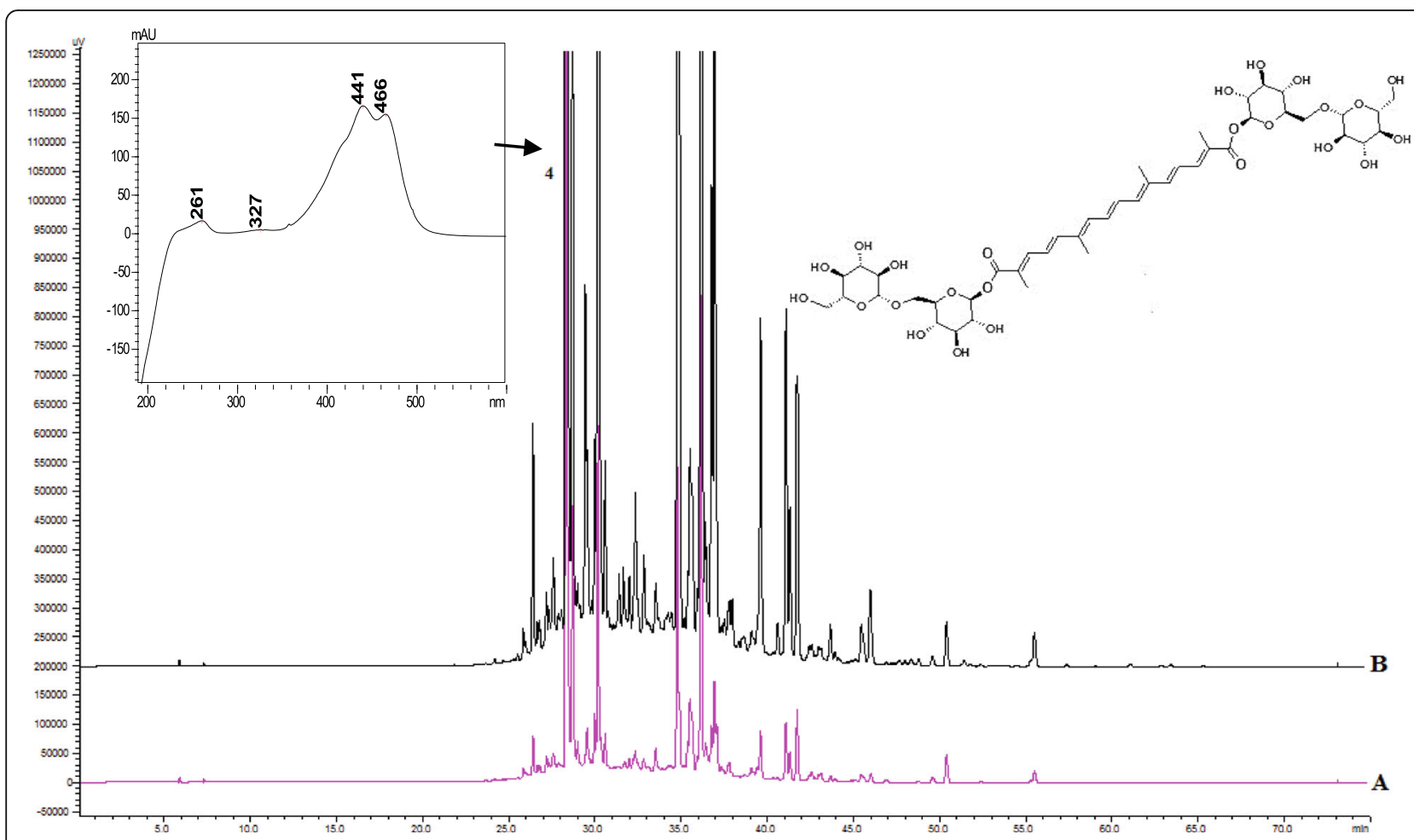

Fig. 2 HPLC-DAD chromatograms of C. sativus stigmas water (A pink line) and hydroethanolic (70\%, v/v) (B black line) crude extracts: crocin (4). The detection wavelength was set at $440 \mathrm{~nm}$

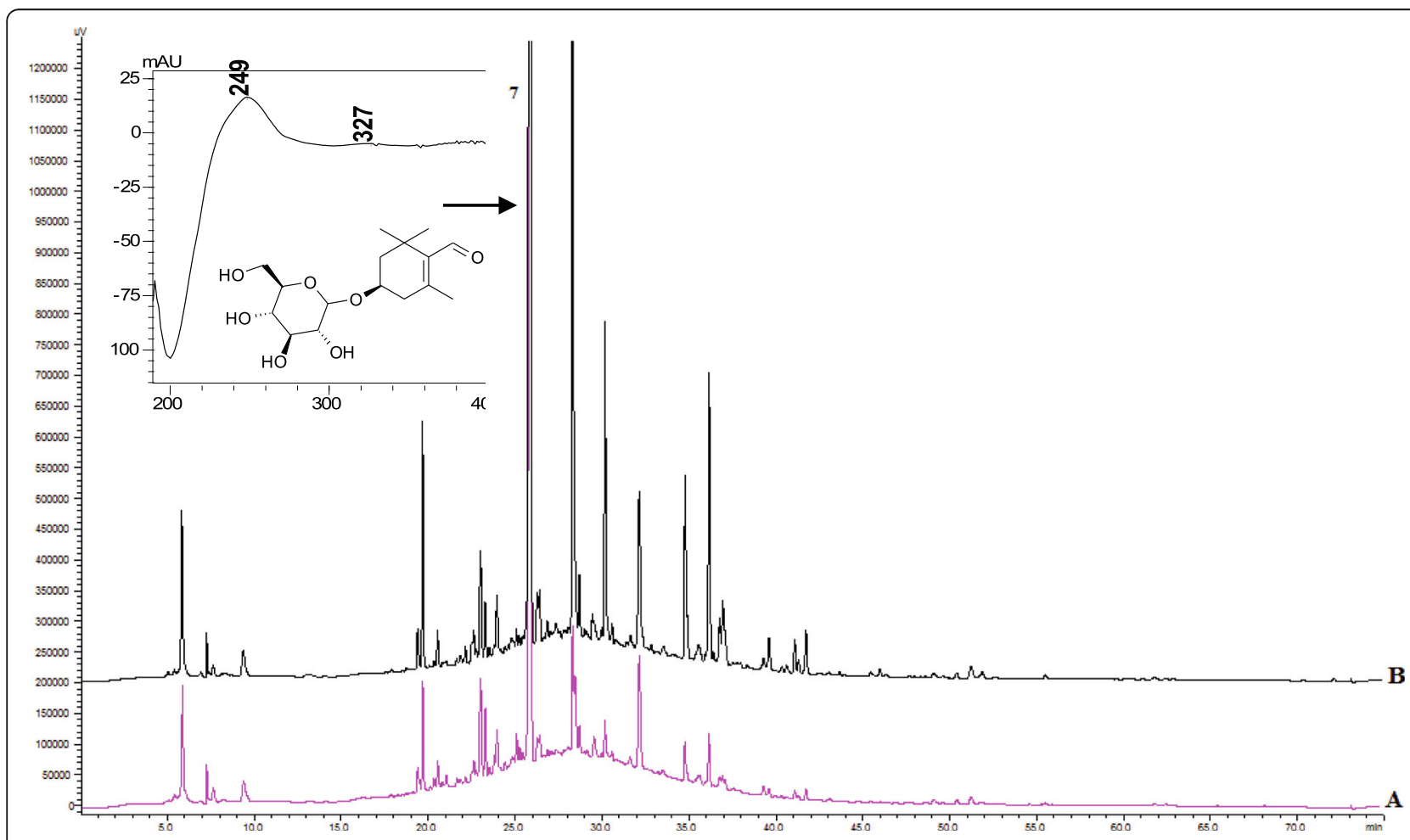

Fig. 3 HPLC-DAD chromatograms of C. sativus stigmas water (A pink line) and hydroethanolic (70\%, v/v) (B black line) crude extracts: picrocrocin. The detection wavelength was set at $250 \mathrm{~nm}$ 
Table 3 The content of biological active compounds (mg/g dry weight) in Crocus sativus stigmas water and hydroethanolic (70\%, v/ v) crude extracts

\begin{tabular}{|c|c|c|c|c|c|}
\hline \multirow[t]{2}{*}{ Compounds } & \multirow{2}{*}{$\begin{array}{l}\text { RT, } \\
\text { min }\end{array}$} & \multirow{2}{*}{$\begin{array}{l}\lambda, \\
\mathrm{nm}\end{array}$} & \multirow{2}{*}{$\begin{array}{l}\text { UV, } \\
\lambda_{\text {max }}, \mathrm{nm}\end{array}$} & \multicolumn{2}{|c|}{ Stigmas extract } \\
\hline & & & & Water & Hydroethanolic \\
\hline \multicolumn{6}{|c|}{ Specific compounds } \\
\hline Crocin & 28.37 & 440 & $261,440,466$ & $38.27 \pm 0.03$ & $163.02 \pm 1.16$ \\
\hline Picrocrocin & 25.88 & 250 & 249,327 & $62.25 \pm 0.10$ & $197.19 \pm 5.60$ \\
\hline Safranal & 55.85 & 310 & 231,312 & $10.81 \pm 0.03$ & $146.66 \pm 3.07$ \\
\hline \multicolumn{6}{|l|}{ Flavonoids } \\
\hline Rutin & 22.48 & 310 & 256,352 & $3.07 \pm 0.02$ & $14.81 \pm 0.41$ \\
\hline Apigenin & 47.90 & 250 & $237,267,337$ & $0.96 \pm 0.01$ & $8.39 \pm 0.15$ \\
\hline \multicolumn{6}{|c|}{ Hydroxycinnamic acids } \\
\hline Caffeic acid & 14.18 & 310 & $217,236,342$ & $0.11 \pm 0.00$ & $0.38 \pm 0.01$ \\
\hline Ferulic acid & 21.64 & 310 & $218,236,323$ & $0.13 \pm 0.03$ & $0.26 \pm 0.00$ \\
\hline
\end{tabular}

The quantitative analysis of the biologically active compounds in the crude extracts showed that crocin (identified as trans-crocetin bis( $\beta$-D-gentiobiosyl) ester), picrocrocin, and safranal were the major components of C. sativus stigmas extracts in agreement with the literature data [27-32]. Previous studies highlighted the importance of these compounds for the biological activities of saffron [2, 3, 8, 9]. In addition to these compounds, the presence of flavonoids with their antiproliferative and cytotoxic activities [34] encouraged us to evaluate the cytotoxic activity of Ukrainian saffron extracts.

\section{Cytotoxic activity of saffron extracts}

The in vitro cytotoxic activity of saffron extracts was investigated against human melanoma IGR39, triplenegative breast cancer MDA-MB-231, and glioblastoma U-87 cell lines (Fig. 4). Hydroethanolic (70\%, v/v) crude extract of $C$. sativus stigmas significantly reduced the viability of breast cancer and melanoma cells in comparison with the water extract. However, the water

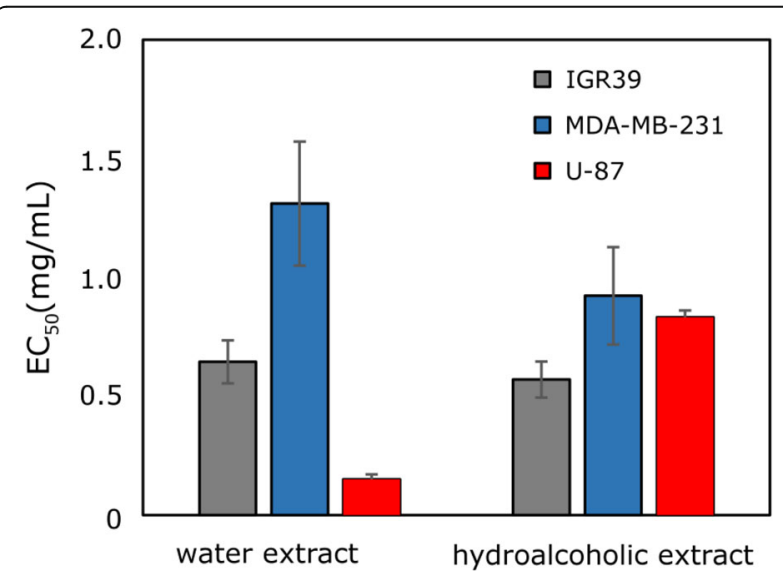

Fig. 4 Cytotoxic activity of the extract against the tested cancer cell lines extract was about 5.6 times more active against the glioblastoma cell line $\left(\mathrm{EC}_{50}\right.$ of the water extract against U87 was $0.15 \pm 0.02 \mathrm{mg} / \mathrm{mL}$, and $\mathrm{EC}_{50}$ of the hydroethanolic extract was $0.83 \pm 0.03 \mathrm{mg} / \mathrm{mL}$ ). The higher activity of Crocus water extract against glioblastoma cell line might be due to the presence of hydrophilic biologically active compounds, such as amino acids, polysaccharides, carboxylic acids [3, 35]. In correlation with our results, several studies on plants such as Inula helenium [36], Usnea longissimi [37], and Tragopogon porrifolius [38] showed that water extracts exhibited higher activity against human U-87 glioblastoma compared with different ethanolic extracts. For instance, the published data [39] indicated that crocetin, a metabolite of major saffron component crocin, exhibited pronounced antitumor properties against U251, U87MG, U373, and U138 glioma cell lines. However, the saffron extract activity against the brain cancer cell line (U-87 cell line) was not reported before.

In other studies, saffron extracts showed antiproliferative activity against several types of cancer cell lines at higher concentrations. For example, C. sativus stigmas methanolic extract demonstrated antiproliferative activity against acute lymphoblastic leukemia cells (Jurkat cell line) $\left(\mathrm{EC}_{50}=71 \pm 2.50 \mu \mathrm{g} / \mathrm{mL}\right)$ [40]. C. sativus stigmas aqueous extract showed a dosedependent inhibitory effect on the growth of human transitional cell carcinoma (TCC 5637) and mouse fibroblast (L929) cell lines at concentrations ranging from $400 \mu \mathrm{g} / \mathrm{mL}$ to $800 \mu \mathrm{g} / \mathrm{mL}$ [41]. Also, the stigmas aqueous extract exhibited a potent dose-dependent antineoplastic effect on highly metastatic murine B16-F10 melanoma cell line $(40.7$ to $73.6 \%$, at 250 to $1000 \mu \mathrm{g} / \mathrm{ml}, 72 \mathrm{~h}$ treatment) [1]. In another study, the cytotoxic effect of saffron stigmas ethanolic extract was evaluated in HepG2 and HeLa cell lines $\left(\mathrm{IC}_{50} 950\right.$ and $800 \mu \mathrm{g} / \mathrm{mL}$, respectively, $48 \mathrm{~h}$ ) [42]. Saffron extract inhibited the 
proliferation of HCT-116 cells by $54.5 \%$ at a concentration of $1 \mathrm{mg} / \mathrm{mL}$ [43]. According to Abd Razak et al. (2017) [44], saffron extract and its main components could affect carcinogenesis in different models in vitro and in vivo.

The saffron demonstrated also other activities related to protection against cancer including radical scavenging activity, anti-mutagenic and immunomodulatory effects $[45,46]$.

\section{Cytotoxic activity of saffron individual compounds}

To better understand how the activity could be related to the chemical composition, we evaluated the $\mathrm{EC}_{50}$ values for several major ingredients of saffron extracts (Fig. 5). According to the results of the current study, the most active substances against the tested breast cancer, melanoma, and glioblastoma cell lines were apigenin and caffeic acid with $\mathrm{EC}_{50}$ values ranging from 123.4 to $197.6 \mu \mathrm{M}$. Other substances (crocin and rutin) did not show cell viability reducing activity even at the highest tested concentrations (up to $1 \mathrm{mM}$, data not shown). The lack of activity of crocin and rutin in our study may be also associated with the specificity towards the selected cell lines. Previous studies on human and animal cancer cell lines demonstrated the cytotoxic activity of saffron as well as its main constituents (crocins, crocetin, safranal, picrocrocin) against leukemia, carcinoma, sarcoma, stomach, liver, prostate, cervix, ovary, breast, skin, lung, and colorectal cancer cell models, often using high concentrations $[2,8,47]$. For instance, the antiproliferative effects of crocin against several cancer and noncancer cell lines were reported, however, a very high concentration was needed to reach an $\mathrm{EC}_{50}$ value [4850]. There is an evidence that high concentrations of crocin $(0.625-10 \mathrm{mg} / \mathrm{mL})$ significantly inhibited HL-60 cell proliferation [48], as well as dose-dependently induced apoptosis and cell cycle arrest at the G2/M phase in MDA-MB-231 cells (approx. $\mathrm{IC}_{50} 5 \mathrm{mg} / \mathrm{mL}, 48 \mathrm{~h}$ ) [49]. The authors, however, studied only the effect of an individual compound, crocin, but did not investigate the

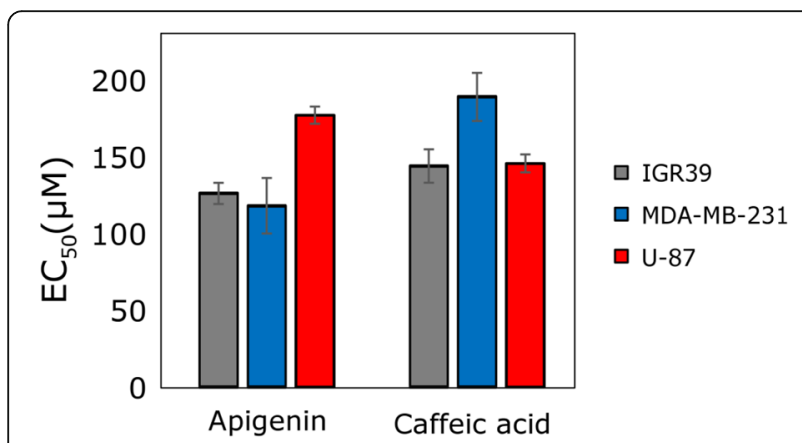

Fig. 5 Anticancer activity of the tested active compounds against different cancer cell lines cytotoxic activity of saffron stigmas whole extract. The cytotoxic bioactivity of crocin and its metabolite crocetin was compared in lung A549, cervical HeLa, ovarian SKOV-3, colorectal HCT-116, liver HepG2 cell lines [50]. Crocetin $\left(\mathrm{EC}_{50}=0.16-0.61 \mathrm{mmol} / \mathrm{L}\right)$, showed 5- to 18 folds higher cytotoxicity than crocin $\left(\mathrm{EC}_{50}=2.0-5.5\right.$ $\mathrm{mmol} / \mathrm{L}$ ) [50] and crocetin further inhibited proliferation glycolytic cancer cell lines $\mathrm{A} 549$ and HeLa $\left(\mathrm{IC}_{50} 0.11\right.$ $\mathrm{mM}$ for both cell lines) as well as lactate dehydrogenase (LDH) [51].

Several studies indicated that $C$. sativus extracts exhibited their cytotoxic effect due to the presence of not only crocin, picrocrocin, safranal, but also a plethora of phenolic compounds.

Apigenin is a common dietary flavonoid that showed the highest activity against melanoma IGR39 and breast cancer MDA-MB-231 cell lines $\left(\mathrm{EC}_{50}\right.$ values were $131.8 \pm 7.2 \mu \mathrm{M}$ and $123.4 \pm 19.0 \mu \mathrm{M}$, respectively) in our experiment (Fig. 5). The activity against the U-87 cell line was lower compared with caffeic acid. The results obtained were consistent with the previously described data [52, 53]. Apigenin reduced MDA-MB-231 cell viability at a similar concentration as in our experiments $(12,27,42$, and $49 \%$ inhibition at $25 \mu \mathrm{M}, 50 \mu \mathrm{M}, 75 \mu \mathrm{M}$ and $100 \mu \mathrm{M}$, respectively) [54]. Apigenin also showed potent antiproliferative effect against human melanoma A375 cell line $\left(\mathrm{EC}_{50}\right.$ was $\left.33.02 \mu \mathrm{M}\right)$ [52]. This activity was higher compared to that against IGR39 cells in our experiments which could be explained by compound specificity against different cell lines. Previous literature showed the antitumor efficacy of apigenin against several types of cancer in vitro and in vivo [55]. For instance, apigenin showed antiproliferative properties against the glioblastoma U1242 and U87 cells [56], and human melanoma A375 and C8161 cells in a concentration- and time-dependent manner [57]. Regarding the molecular basis of its activity, apigenin inhibited cancer cell proliferation by triggering cell apoptosis, inducing autophagy, decreasing cancer cell motility, migration, and invasion [55], and regulating immune response [58]. Multiple signaling pathways were modulated by apigenin, including PI3K/AKT, MAPK/ERK, JAK/STAT, NF-kB, and Wnt/ $\beta$-catenin [55].

In our experiment, caffeic acid showed a similar level of activity against the IGR39 and U-87 cell lines $\left(\mathrm{EC}_{50}\right.$ values were $150.5 \pm 11.4 \mu \mathrm{M}$ and $152.3 \pm 6.2 \mu \mathrm{M}$, respectively), and a slightly lower against the MDA-MB-231 cell line $\left(\mathrm{EC}_{50}\right.$ was $\left.197.6 \pm 16.3 \mu \mathrm{M}\right)$. According to the literature, caffeic acid reduced cell viability against the MCF-7 cell line $\left(\mathrm{EC}_{50} 159 \mu \mathrm{g} / \mathrm{mL}\right)$ [59] and against the HCT15 cell line (approx. $\mathrm{EC}_{50} 800 \mu \mathrm{M}$ ) in time and dosedependent manner [60]. Caffeic acid previously demonstrated cytotoxic activity against SK-Mel-28 human melanoma [61] as well as hepatocellular carcinoma, 


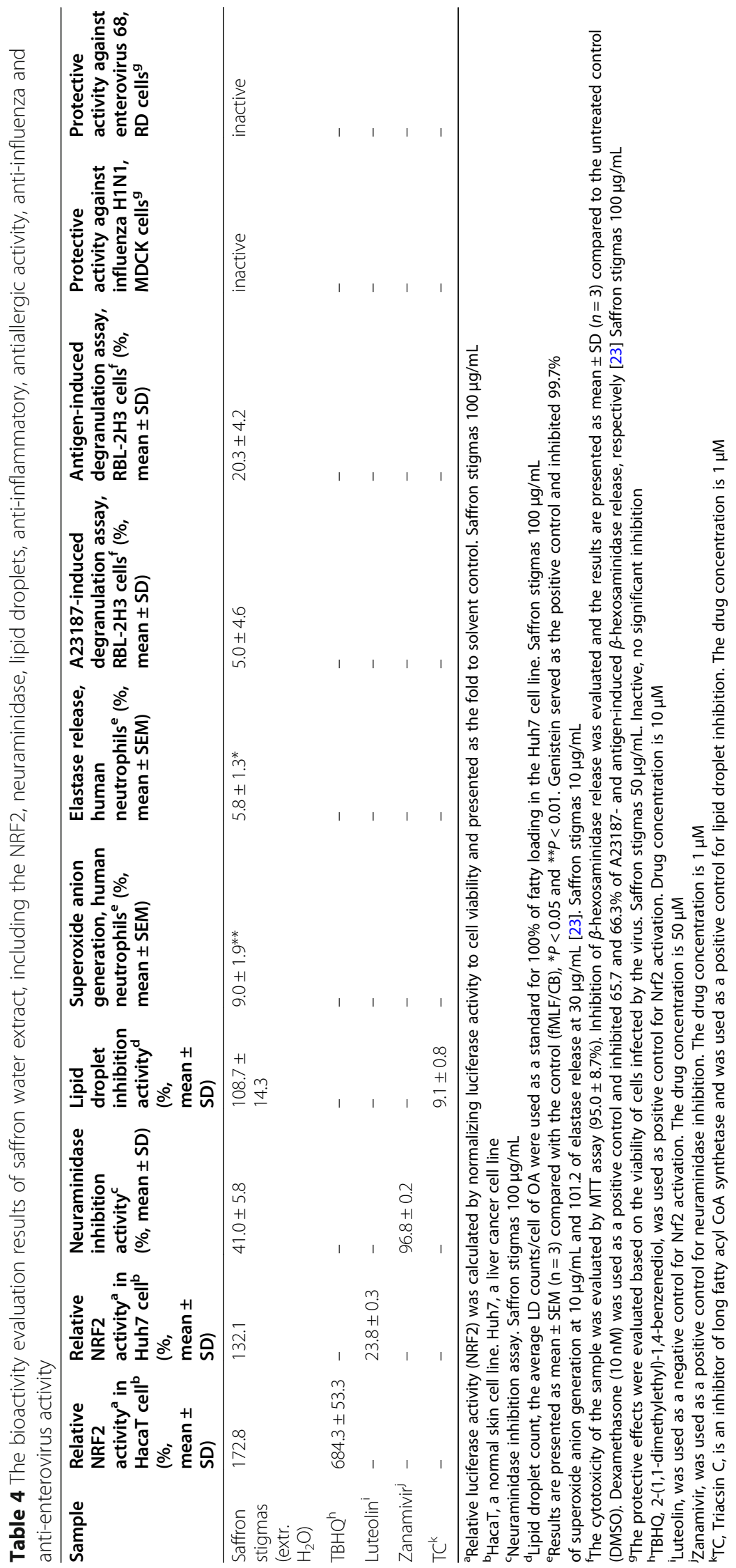




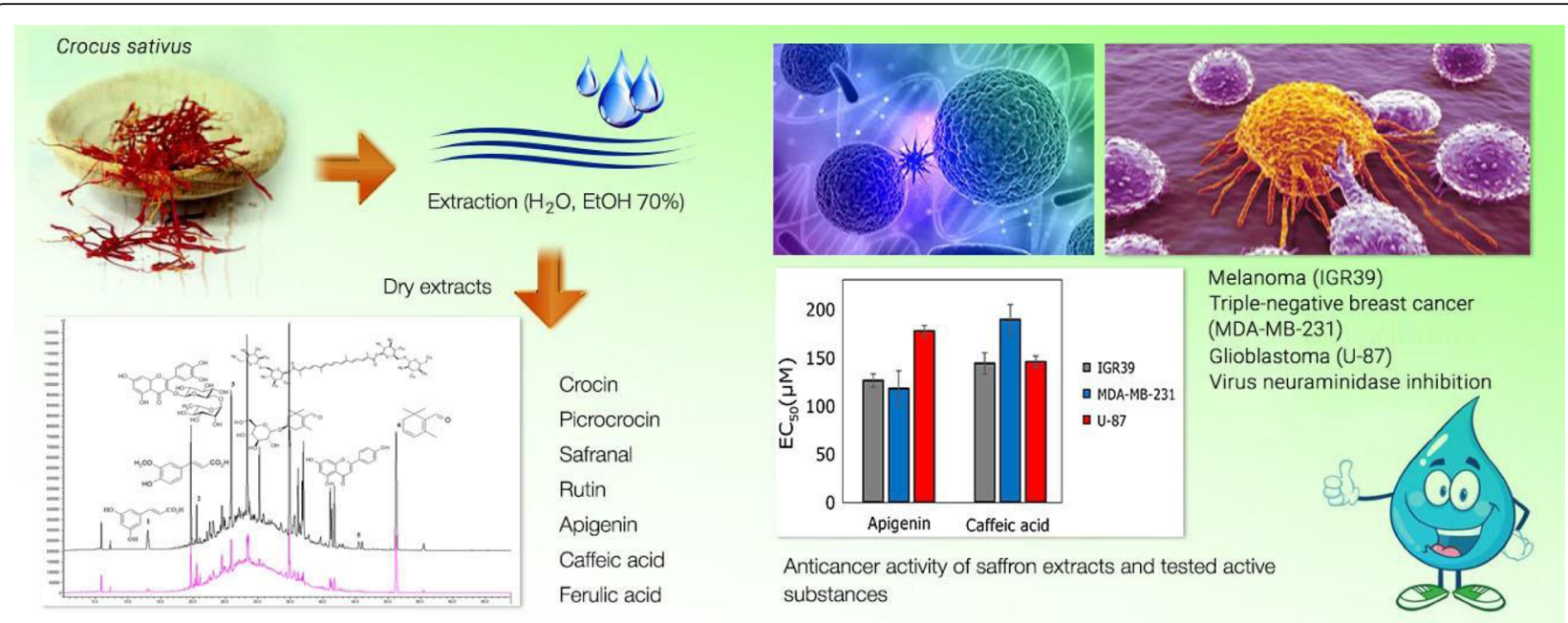

Fig. 6 Overview of the study results on phytochemical analysis and antitumor and other bioactivities of Ukrainian saffron. Antitumor activity against melanoma, triple-negative breast cancer, and glioblastoma cell lines was evaluated in saffron extracts as well as individual compounds

preventing the exaggerated formation of ROS [62]. It promoted the death of tumor cells through DNA oxidation, as well as angiogenesis reduction of VEGF-induced vascularization and the suppression of MMP-2 and MMP-9 expression, acting as antioxidant and prooxidant at the same time [62].

Rutin is a flavonol that demonstrated several pharmacological activities, including antioxidant, cytoprotective, vasoprotective, anticarcinogenic, neuroprotective, and cardioprotective activities [63]. According to different studies, rutin could cause a significant reduction in tumor size justifying its antileukemic potential [64]. Rutin is also known to inhibit cancer cell growth by cell cycle arrest and/or apoptosis along with the inhibition of proliferation, angiogenesis, and/or metastasis in colorectal cell lines [63]. However, in our study rutin did not show a substantial cell growth inhibition towards IGR39, MDA-MB-231, or U-87 cells at concentration up to 1 $\mathrm{mM}$ (data not shown).

Previous literature data indicated that saffron extracts and their constituents, crocin, crocetin, and safranal, apigenin or caffeic acid exhibited a selective toxic effect against cancer cells while toxicity against normal cells was negligible in vitro $[56,62,65,66]$ or in vivo $[67,68]$. The molecular mechanisms of saffron extract and its active components are not yet fully understood, and further studies are needed to justify the use of saffron extracts in cancer treatment.

\section{Bioactivity screening and anti-neuraminidase activity}

For the preliminary bioactivity analysis, the water extract of $C$. sativus stigmas was selected aiming to use the most eco-friendly solvent. There is a lack of studies on the anti-neuraminidase, anti-inflammatory, and antiviral activity of the stigmas extracts. According to the results (Table 4), the water extract $(100 \mu \mathrm{g} / \mathrm{mL})$ inhibited neuraminidase enzymatic activity by $41.0 \%$ in comparison with the positive control, zanamivir $(97.4 \%$ at $1 \mu \mathrm{M})$. Phenolic compounds including apigenin, rutin, and caffeic acid were detected in Ukrainian saffron. Previous studies indicated that plant extracts rich in phenolic content inhibited the enzymatic activity of viral neuraminidase [69]. Also, the amino acid composition of the plant extracts was shown to determine the activity against influenza A virus neuraminidase [70, 71]. In our previous investigation, we studied the composition of amino acids in the water extract of $C$. sativus stigmas and found high content of amino acids including tyrosine $(326.6 \mu \mathrm{g} / \mathrm{g})$, methionine $(84 \mu \mathrm{g} / \mathrm{g})$, and alanine $(60 \mu \mathrm{g} / \mathrm{g})$ [72]. The stigmas extract was inactive in the other bioactivity tests (Table 4), including the antiallergic (degranulation assay, $100 \mu \mathrm{g} / \mathrm{mL}$ ), anti-viral (influenza $\mathrm{H} 1 \mathrm{~N} 1$ and enterovirus D68, $50 \mu \mathrm{g} / \mathrm{mL}$ ), antiinflammatory (respiratory burst and degranulation, $10 \mu \mathrm{g} / \mathrm{mL}$ ), NRF2 expression in normal and cancer cell line $(100 \mu \mathrm{g} / \mathrm{mL})$, and lipid droplets assay $(100 \mu \mathrm{g} / \mathrm{mL})$. Our results together with the literature data suggested that the high content of amino acids as well as the presence of phenolic compounds may correlate with the neuraminidase inhibitory effects of $C$. sativus stigmas water extract, while its higher concentration might be required for the other bioactivities.

\section{Conclusion}

The present study evaluated the cytotoxic activity of Crocus sativus stigmas from Ukraine and correlated results with its major constituents, as identified by HPLC analysis (Fig. 6). The water and hydroethanolic (70\%, v/ 
v) extracts exhibited a cytotoxic effect against melanoma IGR39, triple-negative breast cancer MDA-MB-231, and glioblastoma U-87 cell lines. The water extract of saffron stigmas possessed higher activity than the hydroethanolic extract against U-87 cell lines. This study also described the HPLC method for the qualitative analysis and quantitative determination of apocarotenoids, flavonoids, and phenol carboxylic acids in C. sativus stigmas extracts. Moreover, rutin, apigenin, and ferulic acid were identified in C. sativus stigmas for the first time. Apigenin and caffeic acid showed activity on the selected cancer lines. The results of the current study indicated the need for further research to determine the mechanisms responsible for the established anti-cancer activity.

\section{Abbreviations \\ HPLC: High performance liquid chromatography; MTT assay: Assessing cell metabolic activity; $\mathrm{EC}_{50}$ : Half maximal effective concentration; CB: cytochalasin B; DMEM: Dulbecco's modified Eagle's medium; DMSO: Dimethyl sulfoxide; DNP-BSA: Dinitrophenyl-conjugated bovine serum albumin; FBS: Fetal bovine serum; fMLF: formyl-methionyl-leucyl- phenylalanine; HPLC-DAD: High-performance liquid chromatography coupled with diode array detector; NRF2: Nuclear factor erythroid 2-related factor 2; RBL: Rat basophilic leukemia}

\section{Acknowledgments}

The authors are thankful for the financial support provided by the Science Foundation of Lithuanian University of Health Sciences and Chang Gung University. The authors would like to thank the Center for Research Resources and Development, Kaohsiung Medical University for providing instrumentation support.

\section{Authors' contributions}

O.M., V.P., and M.K. conceived and designed the study; L.I., V.G., and T.-L.H. Funding acquisition; O.M., M.K., I.B., V.P., A.D., C.-H.Y., C.-F.H., and B.-H.C.Chemistry and pharmacology investigation; O.M., VP, and LI. O.M., V.P., and M.K. - Data analysis and interpretation; O.M., M.K., and M.E. - Writing original draft; M.E., V.G., and T.H. - Writing - review \& editing. V.G. and T.H. Supervision. The authors read and approved the final manuscript.

\section{Funding}

This research was funded by the grants from the Ministry of Science and Technology (MOST 106-2320-B-255-003-MY3 and MOST 108-2320-B-255003-MY3, MOST 109-2320-B-037-004-MY3, MOST 109-2327-B-255-001, MOST 109-2327-B-182-002 and MOST 109-2811-I-006-500), Chang Gung Memorial Hospital (CMRPF1G0241 3, CMRPF1J0051 3, and BMRP450), Chang Gung University (104-6576A3), Kaohsiung Medical University (KMU-DK109002-3), Taiwan. The funders had no role in the study design, data collection, and analysis, decision to publish, or preparation of the manuscript.

\section{Availability of data and materials}

All the materials will be available for research purposes upon request from the corresponding author.

\section{Declarations}

\section{Consent for publication}

Not applicable.

\section{Ethics approval and consent to participate}

The study was conducted according to the guidelines of the Declaration of Helsinki, and with the approval of the Institutional Review Board of Chang Gung Memorial Hospital (IRB No. 201802192A3). Written informed consent was obtained from all subjects involved in the study.

\section{Competing interests}

The authors have no conflicts of interest to declare.

\section{Author details}

'Department of Pharmaceutical Chemistry, National University of Pharmacy of Ministry of Health of Ukraine, 4-Valentinivska st, Kharkiv 61168, Ukraine. ${ }^{2}$ Laboratory of Drug Targets Histopathology, Institute of Cardiology, Lithuanian University of Health Sciences, Sukileliu pr. 13, LT-50162 Kaunas, Lithuania. ${ }^{3}$ Institute of Biotechnology, Life Sciences Center, Vilnius University, Sauletekio al. 7, LT-10257 Vilnius, Lithuania. ${ }^{4}$ Graduate Institute of Natural Products, College of Pharmacy, Kaohsiung Medical University, Kaohsiung 80708, Taiwan. ${ }^{5}$ Department of Biotechnology, College of Life Science, Kaohsiung Medical University, Kaohsiung 80708, Taiwan. ${ }^{6}$ Graduate Institute of Natural Products, College of Medicine, Chang Gung University, Taoyuan 33302, Taiwan. ${ }^{7}$ Research Center for Chinese Herbal Medicine, Research Center for Food and Cosmetic Safety, and Graduate Institute of Health Industry Technology, College of Human Ecology, Chang Gung University of Science and Technology, Taoyuan 33302, Taiwan. ${ }^{8}$ Department of Pharmacognosy, Faculty of Pharmacy, Ain-Shams University, Organization of African Unity Street, Abassia, Cairo 11566, Egypt. ${ }^{9}$ Department of Pharmaceutical Biology, Faculty of Pharmacy and Biotechnology, German University in Cairo, Cairo 11835, Egypt. ${ }^{10}$ The Institute of Biomedical Sciences, National Sun Yat-sen University, Kaohsiung 80424, Taiwan. ${ }^{11}$ Department of Biochemistry and Molecular Biology, College of Medicine, Chang Gung University, Taoyuan 33302, Taiwan. ${ }^{12}$ Lithuanian University of Health Sciences, Department of Analytical and Toxicological Chemistry, A. Mickevičiaus g. 9, 44307 Kaunas, LT, Lithuania. ${ }^{13}$ Department of Anesthesiology, Chang Gung Memorial Hospital, Taoyuan 33305, Taiwan. ${ }^{14}$ Department of Chemical Engineering, Ming Chi University of Technology, New Taipei City 24301, Taiwan.

Received: 6 March 2021 Accepted: 29 June 2021

Published online: 21 July 2021

\section{References}

1. Gismondi A, Serio M, Canuti L, Canini A. Biochemical, antioxidant and antineoplastic properties of Italian saffron (Crocus sativus L.). Am J Plant Sci. 2012;3(11):1573-80. https://doi.org/10.4236/ajps.2012.311190.

2. Mykhailenko O, Kovalyov V, Goryacha O, Ivanauskas L, Georgiyants V. Biologically active compounds and pharmacological activities of species of the genus Crocus, A review. Phytochem. 2019;162:56-89. https://doi.org/10.1 016/j.phytochem.2019.02.004.

3. Mykhailenko O, Lesyk R, Finiuk N, Stoika R, Yushchenko T, Ocheretniuk A, et al. In vitro anticancer activity screening of Iridaceae plants. J Appl Pharm Sci. 2020;10:59-63.

4. Mykhailenko O, Desenko V, Ivanauskas L, Georgiyants V. Standard operating procedure of Ukrainian saffron cultivation according with good agricultural and collection practices to assure quality and traceability. Ind Crop Prod. 2020;151:112376-87. https://doi.org/10.1016/j.indcrop.2020.112376.

5. Shatalova OM, Mykhailenko OO. The experimental study of antiinflammatory activity of extracts from the plants of Iridaceae family. Ukr Biopharm J. 2019;1:39-43.

6. Dwyer AV, Whitten DL, Hawrelak JA. Herbal medicines, other than St. John's wort, in the treatment of depression: a systematic review. Altern Med Rev. 2011;16(1):40-9.

7. Lang-Schwarz C, Melcher B, Haumaier F, Schneider-Fuchs A, Lang-Schwarz K, Krugmann J, et al. Budding, tumor-infiltrating lymphocytes, gland formation, scoring leads to new prognostic groups in World Health Organization low-grade colorectal cancer with impact on survival. Hum Pathol. 2019;89:81-9. https://doi.org/10.1016/.jhumpath.2019.04.006.

8. Mzabri I, Addi M, Berrichi A. Traditional and modern uses of saffron (Crocus sativus). Cosmetics. 2019;6(4):63-74. https://doi.org/10.3390/cosmetics604 0063.

9. Samarghandian S, Borji A. Anticarcinogenic effect of saffron (Crocus sativus L.) and its ingredients. Pharm Res. 2014;6:99-107.

10. WHO guidelines on good agricultural and collection practices (GACP) for Medicinal Plants. Switzerland: World Health Organization; 2003. p. 1-72. http://apps.who.int/iris/bitstream/handle/10665/42783/9241546271. pdf?sequence=1. Accessed 15 July 2021.

11. Guideline on good agricultural and collection practice (GACP) for starting materials of herbal origin. European medicines for human use. London: EMEA; 2006. p. 1-11. https://www.ema.europa.eu/en/documents/scientificguideline/guideline-good-agricultural-collection-practice-gacp-starting-ma terials-herbal-origin_en.pdf. Accessed 15 July 2021. 
12. Atyane LH, Ben El Caid M, Serghini MA, Elmaimouni L. Influence of different extraction methods and the storage time on secondary metabolites of saffron. Int J Eng Res Technol. 2017;6:65-9.

13. Jafari SM, Tsimidou MZ, Rajabi H, Kyriakoudi. Saffron: Science, Technology and Health. 1st Ed. Chapter 16: A. Bioactive ingredients of saffron: extraction, analysis, applications. Sawston: In Woodhead Publishing Series in Food Science, Technology and Nutrition; 2020. p. 261-90. https://doi.org/1 0.1016/B978-0-12-818638-1.00016-2

14. Q2 (R1) Validation of Analytical Procedures: Text and Methodology. CPMP/ ICH/381/95, European Medicines Agency. 1995;1-15. https://www.ema. europa.eu/en/documents/scientific-quideline/ich-q-2-r1-validation-analyticalprocedures-text-methodology-step-5_en.pdf. Accessed 15 July 2021

15. Vilkickyte $G$, Raudone L, Petrikaite V. Phenolic fractions from Vaccinium vitisidaea $\mathrm{L}$. and assessment of their antioxidant and anticancer activities. Antioxidants. 2020;9(12):1261-81. https://doi.org/10.3390/antiox9121261.

16. Korinek M, Chen KM, Jiang YH, El-Shazly M, Stocker J, Chou CK, et al. Antiallergic potential of Typhonium blumei: inhibition of degranulation via suppression of PI3K/PLCY2 phosphorylation and calcium influx. Phytomedicine. 2016;23(14):1706-15. https://doi.org/10.1016/j.phymed.201 6.10.011.

17. Chen BH, Wu PY, Chen KM, Fu TF, Wang HM, Chen CYJ. Antiallergic potential on RBL-2H3 cells of some phenolic constituents of Zingiber officinale (ginger). Nat Prod. 2009;72(5):950-3. https://doi.org/10.1021/ np800555y

18. Korinek M, Tsai YH, El-Shazly M, Lai KH, Backlund A, Wu SF, et al. Antiallergic hydroxy fatty acids from Typhonium blumei explored through ChemGPS-NP. Front Pharmacol. 2017;8:356-36. https://doi.org/10.3389/fpha r.2017.00356.

19. Boyum A. Isolation of mononuclear cells and granulocytes from human blood. Isolation of monuclear cells by one centrifugation, and of granulocytes by combining centrifugation and sedimentation at $1 \mathrm{~g}$. Scand J Clin Lab Invest Suppl. 1968:97:77-89.

20. Korinek M, Hsieh PS, Chen YL, Hsieh PW, Chang SH, Wu YH, et al. Randialic acid $\mathrm{B}$ and tomentosolic acid block formyl peptide receptor 1 in human neutrophils and attenuate psoriasis-like inflammation in vivo. Biochem Pharmacol. 2021;190:114596. https://doi.org/10.1016/j.bcp.2021.114596.

21. Tsai YF, Chu TC, Chang WY, Wu YC, Chang FR, Yang SC, et al. 6-Hydroxy-5,7dimethoxy-flavone suppresses the neutrophil respiratory burst via selective PDE4 inhibition to ameliorate acute lung injury. Free Radic Biol Med. 2017; 106:379-92. https://doi.org/10.1016/j.freeradbiomed.2017.03.002.

22. Yen $\mathrm{CH}$, Chang HS, Yang TH, Wang SF, Wu HC, Chen YC, et al. High-content screening of a Taiwanese indigenous plant extract library identifies Syzygium simile leaf extract as an inhibitor of fatty acid uptake. Int J Mol Sci. 2018;19(7):2130-45. https://doi.org/10.3390/ijms19072130.

23. Mykhailenko O, Korinek M, Ivanauskas L, Bezruk I, Myhal A, Petrikaite V, et al. Qualitative and quantitative analysis of Ukrainian Iris species: a fresh look on their content and biological activities. Molecules. 2020;25(19):4588-612. https://doi.org/10.3390/molecules25194588.

24. Sethy B, Hsieh CF, Lin TJ, Hu PY, Chen YL, Lin CY, et al. Design, synthesis, and biological evaluation of itaconic acid derivatives as potential antiinfluenza agents. J Med Chem. 2019;62(5):2390-403. https://doi.org/10.1 021/acs.jmedchem.8b01683.

25. Hsieh CF, Jheng JR, Lin GH, Chen YL, Ho JY, Liu CJ, et al. Rosmarinic acid exhibits broad anti-enterovirus A71 activity by inhibiting the interaction between the five-fold axis of capsid VP1 and cognate sulfated receptors. Emerg Microbes Infect. 2020;9(1):1194-205. https://doi.org/10.1080/22221 751.2020.1767512

26. Sánchez-Vioque R, Santana-Méridas O, Polissiou M, Vioque J, Astraka K, Alaiz $\mathrm{M}$, et al. Polyphenol composition and in vitro antiproliferative effect of corm, tepal and leaf from Crocus sativus L. on human colon adenocarcinoma cells (Caco-2). J Funct Foods. 2016;24:18-25. https://doi.org/10.1016/j.jff.2016.03. 032.

27. Ordoudi SA, Tsimidou MZ. Production practices and quality assessment of food crops. Dordrecht: Springer; 2004.

28. Caballero-Ortega H, Pereda-Miranda R, Riverón-Negrete L, Hernández JM, Medécigo-Ríos M, Castillo-Villanueva A, et al. Chemical composition of saffron (Crocus sativus L.) from four countries. Acta Hort. 2004;650:321-6.

29. del Campo CP, Carmona M, Maggi L, Kanakis CD, Anastasaki EG, Tarantilis PA, et al. Picrocrocin content and quality categories in different (345) worldwide samples of saffron (Crocus sativus L.). J Agric Food Chem. 2010; 58(2):1305-12. https://doi.org/10.1021/jf903336t.
30. Valle García-Rodríguez M, López-Córcoles H, Alonso GL, Pappas CS, Polissio MG, Tarantilis PA. Comparative evaluation of an ISO 3632 method and an HPLC-DAD method for safranal quantity determination in saffron. Food Chem. 2017;221:838-43. https://doi.org/10.1016/j.foodchem.2016.11.089.

31. Hosseinzadeh $\mathrm{H}$, Younesi HM. Antinocicetive and anti-inflamatory effects of Crocus sativus L. stigma and petals extracts in mice. BMC Pharmacol. 2002;2: $1-8$.

32. Alam P, Elkholy SF, Hosokawa M, Mahfouz SA, Sharaf-aidin MA. Simultaneous extraction and rapid HPLC based quantification of crocin and safranal in Saffron (Crocus sativus L.). Int J Pharm. 2016;8:224-7.

33. Loizzo MR, Marrelli M, Pugliese A, Conforti F, Nadjafi F, Menichini F, et al. Crocus cancellatus subsp. damascenus stigmas, chemical profile, and inhibition of $a$-amylase, $a$-glucosidase and lipase, key enzymes related to type 2 diabetes and obesity. J Enzyme Inhib Med Chem. 2016;31(2):212-8. https://doi.org/10.3109/14756366.2015.1016510.

34. Manthey JA, Guthrie N. Antiproliferative activities of citrus flavonoids against six human cancer cell lines. J Agric Food Chem. 2002;50(21):5837-43. https://doi.org/10.1021/jf020121d.

35. Del Campo CP, Garde-Cerdan T, Sanchez AM, Maggi L, Carmona M, Alonso $G L$. Determination of free amino acids and ammonium ion in saffron (Crocus sativus L.) from different geographical origins. Food Chem. 2009; 114(4):1542-8. https://doi.org/10.1016/j.foodchem.2008.11.034

36. Koc K, Ozdemir O, Ozdemir A, Dogru U, Turkez H. Antioxidant and anticancer activities of extract of Inula helenium (L.) in human U-87 MG glioblastoma cell line. J Cancer Res Ther. 2018;14(3):658-61. https://doi.org/1 0.4103/0973-1482.187289.

37. Emsen B, Ozdemir O, Engin T, Togar B, Cavusoglu S, Turkez H. Inhibition of growth of U87MG human glioblastoma cells by Usnea longissima ach. An Acad Bras Cienc. 2019;91(3):e20180994-1008. https://doi.org/10.1590/0001-3 765201920180994

38. Al-Rimawi F, Rishmawi S, Ariqat SH, Khalid MF, Warad I, Salah Z. Anticancer activity, antioxidant activity, and phenolic and flavonoids content of wild Tragopogon porrifolius plant extracts. Evid Based Complement Alternat Med. 2016;2016:9612490-7.

39. Colapietro A, Mancini A, Vitale F, Martellucci S, Angelucci A, Llorens S, et al. Crocetin extracted from saffron shows antitumor effects in models of human glioblastoma. Int J Mol Sci. 2020;21(2):423-43. https://doi.org/10.33 90/ijms21020423.

40. Makhlouf H, Diab-Assaf M, Alghabsha M, Tannoury M, Chahine R, Saab AM. In vitro antiproliferative activity of saffron extracts against human acute lymphoblastic T-cell human leukemia. Indian J Trad Knowl. 2016;15:16-21.

41. Feizzadeh B, Afshari JT, Rakhshandeh H, Rahimi A, Brook A, Doosti H. Cytotoxic effect of saffron stigma aqueous extract on human transitional cell carcinoma and mouse fibroblast. Urol J. 2008;5(3):161-7.

42. Tavakkol-Afshari J, Brook A, Mousavi SH. Study of cytotoxic and apoptogenic properties of saffron extract in human cancer cell lines. Food Chem Toxicol. 2008;46(11):3443-7. https://doi.org/10.1016/j.fct.2008.08.018.

43. Aung HH, Wang CZ, Ni M, Fishbein A, Mehendale SR, Xie JT, et al. Crocin from Crocus sativus possesses significant anti-proliferation effects on human colorectal cancer cells. Exp Oncol. 2007;29(3):175-80.

44. Abd Razak S, Hamzah MSA, Yee FC, Abdul Kadir MR, Mat Nayan NH. A review on medicinal properties of saffron toward major diseases. Int J Geogr Inf Syst. 2017;23:98-116.

45. Bhandari PR. Crocus sativus L. (saffron) for cancer chemoprevention, a mini review. J Tradit Complement Med. 2015;5(2):81-7. https://doi.org/10.1016/j. jtcme.2014.10.009.

46. Baba SA, Malik AH, Wani ZA, Mohiuddin T, Shah Z, Abbas N, et al. Phytochemical analysis and antioxidant activity of different tissue types of Crocus sativus and oxidative stress alleviating potential of saffron extract in plants, bacteria, and yeast. South African J Botany. 2015;99:80-7. https://doi. org/10.1016/j.sajb.2015.03.194.

47. Chryssanthi DG, Dedes PG, Karamanos NK, Cordopatis P, Lamari FN. Crocetin inhibits invasiveness of MDA-MB-231 breast cancer cells via downregulation of matrix metalloproteinases. Planta Med. 2011;77(02):146-51. https://doi. org/10.1055/s-0030-1250178.

48. Sun $Y, X u$ HJ, Zhao YX, Wang LZ, Sun LR, Wang Z, et al. Crocin exhibits antitumor effects on human leukemia HL-60 cells in vitro and in vivo. Evid Based Complement Alternat Med. 2013:2013:690164-71.

49. Chen SS, Gu Y, Lu F, Qian DP, Dong TT, Ding ZH, et al. Antiangiogenic effect of crocin on breast cancer cell MDA-MB-231. J Thorac Dis. 2019; 11(11):4464-73. https://doi.org/10.21037/jtd.2019.11.18. 
50. Kim SH, Lee JM, Kim SC, Park CB, Lee PC. Proposed cytotoxic mechanisms of the saffron carotenoids crocin and crocetin on cancer cell lines. Biochem Cell Biol. 2014;92(2):105-11. https://doi.org/10.1139/bcb-2013-0091.

51. Granchi C, Fortunato S, Meini S, Rizzolio F, Caligiuri I, Tuccinardi T, et al. Characterization of the saffron derivative crocetin as an inhibitor of human lactate dehydrogenase 5 in the antiglycolytic approach against cancer. J Agric Food Chem. 2017;65(28):5639-49. https://doi.org/10.1021/acs.jafc.7b01 668.

52. Ghițu A, Schwiebs A, Radeke HH, Avram S, Zupko I, Bor A, et al. A comprehensive assessment of apigenin as an antiproliferative, proapoptotic, antiangiogenic and immunomodulatory phytocompound. Nutrients. 2019; 11:1-19.

53. Grigalius I, Petrikaite V. Relationship between antioxidant and anticancer activity of trihydroxyflavones. Molecules. 2017;22:1-12.

54. Chen D, Landis-Piwowar KR, Chen MS, Dou QP. Inhibition of proteasome activity by the dietary flavonoid apigenin is associated with growth inhibition in cultured breast cancer cells and xenografts. Breast Cancer Res. 2007;9(6):R80-8. https://doi.org/10.1186/bcr1797.

55. Yan X, Qi M, Li P, Zhan Y, Shao H. Apigenin in cancer therapy, anti-cancer effects and mechanisms of action. Cell Biosci. 2017;7(1):50-66. https://doi. org/10.1186/s13578-017-0179-x.

56. Stump TA, Santee BN, Williams LP, Kunze RA, Heinze CE, Huseman ED, et al. The antiproliferative and apoptotic effects of apigenin on glioblastoma cells. J Pharm Pharmacol. 2017;69(7):907-16. https://doi.org/10.1111/jphp.12718.

57. Zhao G, Han X, Cheng W, Ni J, Zhang Y, Lin J, et al. Apigenin inhibits proliferation and invasion, and induces apoptosis and cell cycle arrest in human melanoma cells. Oncol Rep. 2017;37(4):2277-85. https://doi.org/10.3 892/or.2017.5450.

58. Cardenas H, Arango D, Nicholas C, Duarte S, Nuovo GJ, He W, et al. Dietary apigenin exerts immune-regulatory activity in vivo by reducing NF-KB activity, halting leukocyte infiltration and restoring normal metabolic function. Int J Mol Sci. 2016;17(3):323-40. https://doi.org/10.3390/ijms1703 0323.

59. Rezaei-Seresht H, Cheshomi H, Falanji F, Movahedi F, Hashemian M, Mireskandari E. Cytotoxic activity of caffeic acid and gallic acid against MCF7 human breast cancer cells, an in silico and in vitro study. Avicenna J Phytomed. 2019;9(6):574-86. https://doi.org/10.22038/AJP.2019.13475.

60. Jaganathan SK. Growth inhibition by caffeic acid, one of the phenolic constituents of honey, in HCT15 colon cancer cells. Sci World J. 2012;2012: 372345-53.

61. Pelinson LP, Assmann CE, Palma TV, da Cruz IBM, Pillat M, Mânica A, et al. Antiproliferative and apoptotic effects of caffeic acid on SK-Mel-28 human melanoma cancer cells. Mol Biol Rep. 2019;46(2):2085-92. https://doi.org/1 0.1007/s11033-019-04658-1.

62. Espíndola KMM, Ferreira RG, Narvaez LEM, Silva Rosario ACR, da Silva AHM, Silva AGB, et al. Chemical and pharmacological aspects of caffeic acid and its activity in hepatocarcinoma. Front Oncol. 2019;9:541-51. https://doi.org/1 0.3389/fonc.2019.00541.

63. Ganeshpurkar A, Saluja AK. The pharmacological potential of rutin. Saudi Pharm J. 2017;25(2):149-64. https://doi.org/10.1016/j.jsps.2016.04.025.

64. Lin JP, Yang JS, Lin JJ, Lai KC, Lu HF, Ma CY, et al. Rutin inhibits human leukemia tumor growth in a murine xenograft model in vivo. Environ Toxicol. 2012;27(8):480-4. https://doi.org/10.1002/tox.20662.

65. Hoshyara R, Mollaei $\mathrm{H}$. A comprehensive review on anticancer mechanisms of the main carotenoid of saffron, crocin. J Pharm Pharmacol. 2017;69(11): 1419-27. https://doi.org/10.1111/jphp.12776.

66. Moradzadeh M, Kalani MR, Avan A. The antileukemic effects of saffron (Crocus sativus L.) and its related molecular targets: a mini review. J Cell Biochem. 2019;120(4):4732-8. https://doi.org/10.1002/jcb.27525.

67. Milajerdi A, Djafarian K, Hosseini B. The toxicity of saffron (Crocus sativus L.) and its constituents against normal and cancer cells. J Nutr Int Metab. 2016; 3:23-32.

68. Hosseinzadeh H, Sadeghi Shakib S, Khadem Sameni A, Taghiabadi E. Acute and subacute toxicity of safranal, a constituent of saffron, in mice and rats. Iran J Pharm Res. 2013;12(1):93-9.

69. Liu J, Zu M, Chen K, Gao L, Min H, Zhuo W, et al. Screening of neuraminidase inhibitory activities of some medicinal plants traditionally used in Lingnan Chinese medicines. BMC Complement Altern Med. 2018; 18(1):102-13. https://doi.org/10.1186/s12906-018-2173-1.

70. Kobasa D, Wells K, Kawaoka Y. Amino acids responsible for the absolute sialidase activity of the influenza a virus neuraminidase: relationship to growth in the duck intestine. J Virol. 2001;75(23):11773-80. https://doi.org/1 0.1128/JVI.75.23.11773-11780.2001.

71. Kati WM, Montgomery D, Maring C, Stoll VS, Giranda V, Chen X, et al. Novel alpha- and beta-amino acid inhibitors of influenza virus neuraminidase. Antimicrob Agents Chemother. 2001;45(9):2563-70. https://doi.org/10.112 8/AAC.45.9.2563-2570.2001.

72. Mykhailenko O, Ivanauskas L, Bezruk I, Lesyk R, Georgiyants V. Comparative investigation of amino acids content in the dry extracts of Juno bucharica, Gladiolus hybrid zefir, Iris hungarica, Iris variegata and Crocus sativus raw materials of Ukrainian flora. Sci Pharm. 2020;88(1):8-21. https://doi.org/10.33 90/scipharm88010008.

\section{Publisher's Note}

Springer Nature remains neutral with regard to jurisdictional claims in published maps and institutional affiliations.
Ready to submit your research? Choose BMC and benefit from:

- fast, convenient online submission

- thorough peer review by experienced researchers in your field

- rapid publication on acceptance

- support for research data, including large and complex data types

- gold Open Access which fosters wider collaboration and increased citations

- maximum visibility for your research: over $100 \mathrm{M}$ website views per year

At BMC, research is always in progress.

Learn more biomedcentral.com/submissions 